\title{
Yellow Cassava Attributes Influencing its Utilization among Cassava Processors in Oyo State, Nigeria.
}

\author{
R. G. Adeola ${ }^{1}$, K. Y. Ogunleye ${ }^{1 *}$, I. F. Bolarinwa ${ }^{2}$ \\ ${ }^{1}$ Department of Agricultural Extension and Rural Development, Ladoke Akintola University of Technology (LAUTECH) \\ Ogbomoso, Oyo State, Nigeria. \\ ${ }^{* 2}$ Department of Food Science and Engineering, Ladoke Akintola University of Technology (LAUTECH), Ogbomoso, Oyo \\ State, Nigeria.
}

\begin{abstract}
The research focused on attributes determining utilization of Yellow cassava (YC) varieties. Two of the four agricultural zones in the state namely; Ogbomoso and Oyo zones were covered in the study. Structured interview schedules were used to elicit information from 302 cassava processors who were selected through multi-stage sampling procedure. Data was presented using descriptive statistics and analysed with inferential statistical tools. Findings showed age of respondents was 46 years, about $92 \%$ were females with more than two-thirds (75.5\%) having formal education. Awareness of YC was substantial among sampled processors. Virtually all the respondents (99.3\%) claimed to be aware of TMS 01/1368 variety of YC and majority were using this particular variety. Extension agents from Oyo State Agricultural Development Programme (OYSADEP), Harvest plus and International Institute of Tropical Agriculture (IITA) formed leading sources of information on YC varieties among the respondents. Gari and Fufu were the common products people in the study area made from YC. The processors are favourably disposed to utilization of YC. Critical constraints faced in the utilization of YC were non availability of market for $Y C$ products and inadequate information on the potentials of yellow root cassava. Pearson Product Moment Correlation revealed that taste of YC products $(r=0.813)$, consumer's acceptability of the products $(r=0.758)$ and multiple usage of the YC $(r=0.818)$ are important attributes that influences the utilization of YC. More awareness campaign on potential of YC should be made so as to create market for its products thereby increasing the income of the processors.
\end{abstract}

Keywords- Yellow cassava, Processors, Utilization, Vitamin A, Attributes.

\section{INTRODUCTION}

Globally, Vitamin A deficiency (VAD) is the world's commonest cause of blindness among children. Approximately 228 million children are affected sub- clinically and 500,000 children become partially or totally blind every year due to VAD \{World Health Organization(WHO)/Food and Agricultural Organization(FAO), 2003\}. Therefore, VAD has been a major public health problem in many developing countries. In Nigeria, about 30 percent of children under age five and almost $20 \%$ of pregnant women are deficient in micronutrients like Vitamin A. Vitamin A deficiency in children leads to stunted growth, diarrhoea, measles and premature death. According to Maziya-Dixon et al., (2007) and Worid Health Organizations (2017), Vitamin A deficiency can cause severe night blindness and high mortality rate in pregnant women.

Many Nigerians irrespective of age, gender and geographical location get less Vitamin A than the required amount. The major determinants of Vitamin A deficiency are low availability and inadequate consumption of Vitamin A diets. Animal foods that are good sources of Vitamin A are not affordable by the poor communities and thus leaving foods of plant origin as an important source of pro-Vitamin A in developing countries (Tumuhimbise et al,2013). Recognizing the severity of the problem, Nigerian government had embarked on supplementation programs with Vitamin A for children within the age range of 6 months to 5 years during immunization days and has mandated the fortification of certain food items like sugar, wheat flour and vegetable oil with Vitamin A since the year 2000. In order to combat the prevalence of VAD, various strategies including fortification and bio-fortification methods have been developed by scientists across the world (www.harvestplus.org). Cassava (Manihot esulenta Crantz.), is the chief source of dietary food energy for the majority of the people living in the low land tropics and much of the sub-humid tropics of west and central Africa (Echebiri and Edaba, 2008). Cassava is a hardy crop that is extremely adaptable to severe weather conditions and drought tolerant. It can grow well on soils of limited fertility. Cassava is an important food and subsistence 
crop in Nigeria and one of the staple foods generally consumed by the majority of the populace that is vulnerable to VAD. It has been estimated that 600-700 million people obtain more than 500 calories/day from cassava (Maziya-Dixon et al., 2007; Nuwamanya et. al., 2010) but the commonly available white cassava lacks micro nutrients like Vitamin A (www.harvestplus, 2014). Economic problems, political unrest, reduced soil fertility, drought, and the population explosion all have increased the need for cassava as a cheap, common, versatile crop that is resistant to adverse environmental factors, such as poor soil fertility, drought (Osiru et. al., 1992) and disease (Asonye, 2001). Considering the important role of cassava in the diets of Nigerians, National Root Crops Research Institute (NCRI) Umudike and International Institute of Tropical Agriculture (IITA), Ibadan jointly developed cassava varieties bio-fortified with Vitamin A in order to complement government efforts to check Vitamin A deficiency and malnutrition in the country. These varieties are yellow in colour owing to their high beta-carotene (pro-Vitamin A ) content; hence they are called Yellow Cassava. The new yellow varieties are also high yielding and resistant to major diseases and pests. It is strongly believed that the YC varieties being introduced to farmers would be an effective tool in reducing VAD among poor people.

This study;

1. described the socio-economic and enterprise characteristics of the processors

2 determined extent of awareness and utilization of YC varieties

3. investigated the processors' perception of yellow cassava,

4. determined level of yellow cassava utilisation

5. identified YC attributes that determines its use by the processors

6. know constraints to the utilization of YC

7. identified factors influencing the utilization of $\mathrm{YC}$

\section{METHODOLOGY}

Four (4) Local Government Areas (LGAs) were purposively selected for the survey because they were noted for production and consumption of cassava in large quantity and formed part of the targeted areas by the Oyo State Agricultural Development Programme (OYSADEP) for YC introduction and delivery. The LGAs included in the survey were; Afijio and Ojongbodu in Oyo Agricultural zone while Orire and Surulere LGAs were selected in Ogbomoso Agricultural zones of the state. All the villages with a high concentration of cassava processors in the selected LGAs were listed through the assistance of OYSADEP Women In Agriculture (WIA) extension agents and two villages were randomly selected from each LGA; thus a total of eight (8) villages for the www.ijeab.com four (4) LGAs selected for the survey. The WIA agents were tasked to make the list of all the processors within the selected villages which resulted in sampling frame of 604 from which fifty (50) percent (302) of the processors were randomly selected to form the sample for the study. Interview schedule was developed and used to collect data for the study. The processors were asked to give their ratings of cassava attributes that will encourage the utilisation of cassava using a Likert type scale ranging from 3 (very important) to 1 (somewhat inmportant). Processors' perception of $\mathrm{YC}$ and its products were operationalized as follows: Strongly Agreed $(\mathrm{SA})=5$, Agree $(A)=4$, Undecided $(\mathrm{U})=3$, Disagree $(\mathrm{D})=2$ and Strongly Disagreed $(\mathrm{SD})=1$ for positive statements and these values were reversed for the negative statements. Data collected was subjected to descriptive ( frequency counts, percentage distribution, mean standard deviation) and inferential statistics (Chi-square and Pearson Product Moment Correlation) at $\mathrm{p} 0.05$

\section{RESULTS AND DISCUSSION}

\subsection{Socio-economic characteristics of the} respondents

Results in Table 1 revealed that few (4.3\%) of the processors were within the age group of 20 to 29 years, majority were between 30 and 49 years while $33.8 \%$ were within the age group of 50 to 69 years. The mean age of the processors was 46 years and as such, an average processor in the study area is still economically active and could result in a positive effect on adoption as he or she would be willing to take risks in expectation of more profit.

Majority $(92.4 \%)$ of the respondents were females. The implication of this is that females are most active and involved when it comes to garri processing in the study area. This corroborates the findings of Nweke et al.,(2002) and Ogunleye, Olaniyi and Adedeji (2012) that women specializes in cassava processing. Also, 94.4\% of the respondents were married while others were either single or divorced. This could help in the dissemination of information, because according to Ojo and Jibowu (2008), married people being responsible, their views are likely to be respected within rural communities as they take decisions on the use of agricultural inputs.

Education is very important for farmers to understand and interpret any agricultural information coming to them from any direction. It enables one to access information needed to use and practice an innovation. About $76 \%$ of the respondents had formal education while others had no formal education. Given this level of literacy, the implication is that information could be disseminated with ease among the processors. Majority $(66.6 \%)$ of the respondents spent between 1 and 9 years in obtaining basic education, while only a few $(0.7 \%)$ spent between

Page | 2651 
20 and 29 years in obtaining basic education. The average number of years spent in obtaining basic education by respondents was approximately 7 years. This implies that the level of education of the processors was low although they had one form of education or the other.

Household size is considered to be the number of individuals who reside in a family. Large household size is assumed as an indicator of labour availability in the family. Table 1 further shows majority $(94.0 \%)$ of the respondents interviewed had between $1-10$ household members, while only $0.7 \%$ had between 21 - 30 members within their household. The average number of members within a household is 6. Very few (9.6\%) of the respondents used family labour, $44.7 \%$ used hired labour for processing activities while $45.7 \%$ used both family and hired labour. This might be due to the small household size. Findings also showed that majority (74.5\%) received information about YC through Oyo State Agricultural Development Programme (OYSADEP), $43.0 \%$ obtained information through relations while $4.0 \%$ and $6.0 \%$ of the respondents obtained information through Harvest Plus and International Institute for Tropical Agriculture respectively.

Table.1: Distribution of respondents' socio-economic characteristics

\begin{tabular}{|c|c|c|c|}
\hline Socio-Economic Characteristics & Category & Frequency & Percentage \\
\hline \multirow[t]{2}{*}{ Age (Years) } & $20-29$ & 13 & 4.3 \\
\hline & $30-39$ & 74 & 24.5 \\
\hline Mean $=45.78$ & $40-49$ & 113 & 37.4 \\
\hline \multirow[t]{2}{*}{$\mathbf{S D}=(9.847)$} & $50-59$ & 66 & 21.9 \\
\hline & $60-69$ & 36 & 11.9 \\
\hline \multirow[t]{2}{*}{ Sex } & Male & 23 & 7.6 \\
\hline & Female & 279 & 92.4 \\
\hline \multirow[t]{3}{*}{ Marital status } & Single & 4 & 1.3 \\
\hline & Married & 285 & 94.4 \\
\hline & Divorced & 13 & 4.3 \\
\hline \multirow[t]{4}{*}{ Educational status } & No Formal Education & 74 & 24.5 \\
\hline & Primary Education & 132 & 43.7 \\
\hline & Secondary Education & 79 & 26.2 \\
\hline & Tertiary Education & 17 & 5.6 \\
\hline \multirow[t]{2}{*}{ Years spent in school } & $\mathbf{0}$ & 74 & 24.5 \\
\hline & $1-9$ & 127 & 42.0 \\
\hline Mean $=6.85$ & $10-19$ & 99 & 32.8 \\
\hline $\mathbf{S D}=(5.132)$ & $\geq 20$ & 2 & 0.7 \\
\hline Household size (People) & $1-10$ & 284 & 94.0 \\
\hline Mean=6.39 & $11-20$ & 16 & 5.3 \\
\hline $\mathrm{SD}=(\mathbf{3 . 0 3 6})$ & $21-30$ & 2 & 0.7 \\
\hline \multirow[t]{2}{*}{ Religion } & Islam & 142 & 47.0 \\
\hline & Christianity & 160 & 53.0 \\
\hline \multirow[t]{3}{*}{ Source of labour } & Family & 29 & 9.6 \\
\hline & Hired & 135 & 44.7 \\
\hline & Both & 138 & 45.7 \\
\hline \multirow[t]{4}{*}{ Source of information* } & Extension Agents & 225 & 74.5 \\
\hline & Family Relations & 130 & 43.0 \\
\hline & Harvest Plus & 12 & 4.0 \\
\hline & IITA & 18 & 6.0 \\
\hline
\end{tabular}

Note: * multiple responses

3.2 Enterprise characteristics of the processors
Table 2 shows majority $(92.7 \%)$ of the processors used local method for processing while very few (7.3\%) used 
improved method. This might be because of sharp reduction in carotenoid content due to losses during processing (Aniedu and Omodamiro, 2012).

The result further revealed that $61.0 \%$ had spent between 10 and 29 years in cassava processing, with the average number of years being 21 years. It shows the processors are veterans in cassava processing. About $92.0 \%$ of the respondents are into farming and had farm size of less than 10 hectares, $7.3 \%$ had 10 to 29 hectares while very few $(0.7 \%)$ had above 30 hectares. Nonetheless, their average farm size was approximately 3 hectares. However, $93.4 \%$ used 5hectares or less to cultivate cassava while $4.6 \%$ used 6 to 10 hectares and $0.7 \%$ cultivated 16 to 20 hectares. The average land cultivated to cassava was 2 hectares meaning they are not large scale farmers.

The result further revealed that only about half $(53.3 \%)$ of the respondents used 1 hectare to cultivate $\mathrm{YC}$ while very few $(6.0 \%)$ used 2 ha but $40.7 \%$ did not cultivate YC. This implies that majority of the processors operate on a small scale production in the study area. This is because they had farm size of less or equal to 5 hectares which is considered as small scale based on classification of Federal Office of Statistics (1999). This supports Erhabor and Emokwo (2007) who stated that most cassava farmers' are small-holder farmers.

Furthermore, majority $(74.5 \%)$ of the respondents obtained their planting materials from other farmers while the remaining $(25.5 \%)$ obtained their planting materials from either IITA or relatives. Extension visits afford farmers easy exposure to new technologies, how to go about them and the benefits. The greater the visits by extension agents, the better the farmers are informed about new technology (Manyong and Houndekon, 1997; Wejnert, 2002; Berisso, 2008). Furthermore, majority $(72.5 \%)$ of the respondents had contact with extension agent, though the frequency of contacts was not the same. The reason for the respondents' access to extension agents may be due to membership of social organization. It could therefore be seen that extension visits is a determinant of investment decision in new technologies. Therefore, Oseni et al. (2015) posited that farmers, through extension visits become better informed about farm management planning and new technologies, hence improving their efficiency in production. Result also revealed that all the respondents were aware of $\mathrm{YC}$ as $33.8 \%$ had been aware for 1 to 2 years, $64.2 \%$ had been aware for 3 to 4 years while very few $(2.0 \%)$ had been aware for 5 or more years. Majority $(74.2 \%)$ of the respondents in the study area preferred the yellow variety of cassava to the white variety. The reason for their preference was adduced to the fact that products from YC sells faster, the $\mathrm{YC}$ gives more product after processing, and that there are more buyers for the products. This finding corroborates Oparinde et al. (2014) that yellow cassava products is most preffered in Oyo state.

Table.2: Enterprise characteristics of the respondents

\begin{tabular}{|l|l|r|r|}
\hline Enterprise characteristics & Category & Frequency & Percentage \\
\hline Methods of processing & Local method & 280 & 92.7 \\
\hline & Improved method & 22 & 7.3 \\
\hline Years spent in Cassava processing & $1-9$ & 36 & 11.9 \\
\hline & $10-19$ & 89 & 29.5 \\
\hline Mean=21.04 & $20-29$ & 95 & 31.5 \\
\hline SD $=(9.823)$ & $30-39$ & 66 & 21.9 \\
\hline & $40-49$ & 16 & 5.3 \\
\hline Farm size (Ha) & $<10$ & 278 & 92.1 \\
\hline Mean=3.25 & $10-19$ & 14 & 4.6 \\
\hline SD $=(4.688)$ & $20-29$ & 8 & 2.7 \\
\hline & $>30$ & 2 & 0.7 \\
\hline Farm size planted to cassava (ha) & $\leq 5$ & 282 & 93.4 \\
\hline Mean=2.00 & $6-10$ & 14 & 4.6 \\
\hline SD $=(2.385)$ & $>10$ & 6 & 2.0 \\
\hline Farm size planted to YC (ha) & 0 & 123 & 40.73 \\
\hline Mean=0.69 & 1 & 161 & 53.31 \\
\hline SD $=(0.439)$ & 2 & 18 & 5.96 \\
\hline Source of planting materials & IITA & 60 & 19.9 \\
\hline & Self/Relative & 17 & 5.6 \\
\hline & Other farmers & 117 & 38.7 \\
\hline Contact with extension agent & Contact & 219 & 72.5 \\
\hline & Non-contact & 83 & 27.5 \\
\hline
\end{tabular}




\begin{tabular}{|l|r|r|r|}
\hline Enterprise characteristics & Category & Frequency & Percentage \\
\hline Years of awareness of YC varieties (years) & $1-2$ & 102 & 33.8 \\
\hline & $3-4$ & 194 & 64.2 \\
\hline Preferred Cassava variety & $\geq 5$ & 6 & 2.0 \\
\hline & Yellow & 224 & 74.2 \\
\hline
\end{tabular}

\section{* Multiple responses recorded}

3.3 Awareness of white and yellow varieties of cassava

According to Agricultural Development Office in Ogbomoso agricultural zone, three varieties were introduced namely; TMS 01/1368, TMS01/1412 and TMS01/1371. From the findings of the study $99.3 \%$ of the processors were aware of TMS 01/1368 while $95.7 \%$ used the variety by processing into products. This implies TMS
$01 / 1368$ is the most adopted YC variety and the least adopted was TMS01/1412. Lack of awareness and poor use of other varieties might be because the varieties did not trive well in the area. This is similar to the findings of Umunakwe et al (2015) that low planting of some cassava varieties by farmers could be due to farmers unfamiliarity of the varieties and lack of desirable characteristics that may encourage their cultivation.

Table.3: Extent of awareness and utilization of YC varieties

\begin{tabular}{|c|c|c|c|c|}
\hline Varieties & Aware & Unaware & Using & Not using \\
\hline TMS 01/1368 & $300(99.3)$ & $2(0.7)$ & $287(95.67)$ & $15(5.0)$ \\
\hline TMS01/1412 & $25(8.3)$ & $277(91.7)$ & $14(4.6)$ & $288(95.4)$ \\
\hline TMS01/S371 & $62(20.5)$ & $240(79.5)$ & $60(19.9)$ & $242(80.1)$ \\
\hline
\end{tabular}

3.4 Frequency of YC processing, quality and attractiveness of product

Majority $(85.1 \%)$ of the respondents always make Garri from YC while $13.6 \%$ occasionally make Garri from YC. About $42 \%$ occasionally make Lafun from YC. This might be due to the colour that the $\mathrm{YC}$ will bring out in the making of Lafun which will nonetheless affect its sale. Findings also showed that most $(35.4 \%$ and $35.1 \%)$ of the respondents either rarely or always make fufu from YC respectively while only $27.5 \%$ occasionally make fufu from YC. Results also revealed that majority $(68.5 \%)$ of the respondents never make starch from YC while only $22.2 \%$ of the respondents rarely make starch from this variety of cassava. Also, majority (69.5\% and 93.4\%) of the respondents never make chips and cassava cake from YC. This could be due to their acceptability in the market. Almost all (98.7\%) the respondents claimed that Garri made from YC had an excellent taste; $43.7 \%$ and $46.0 \%$ claimed that Lafun and Fufu made from this variety of cassava tasted good respectively. Majority (93.7\%) of the respondents believed that Garri made from YC had a very attractive colour, while about half $(50.7 \%)$ of the respondents believed that Lafun made from YC was attractive. Also, $62.9 \%$ of the respondents were convinced that the colour of the Fufu made from YC was attractive while $45.4 \%$ claimed that the colour of cassava chips made from YC was attractive (Table 4).

Table.4: Respondents' frequency of YC processing, quality and attractiveness of product

\begin{tabular}{|c|c|c|c|c|}
\hline Frequency of YC processing & Gari & Lafun & Fufu & Cassava Chips \\
\hline Always & $257(85.1)$ & $14(4.6)$ & $106(35.1)$ & $2(0.7)$ \\
\hline Occasionally & $41(13.6)$ & $126(41.7)$ & $83(27.5)$ & $0(0)$ \\
\hline Rarely & $4(1.3)$ & $28(9.3)$ & $107(35.4)$ & $18(6.0)$ \\
\hline Never & $0(0)$ & $134(44.4)$ & $6(2.0)$ & $282(93.4)$ \\
\hline Quality of product & \multicolumn{5}{|l}{} \\
\hline Excellent & $298(98.7)$ & $6(2.0)$ & $74(24.5)$ & $33(10.9)$ \\
\hline Good & $2(0.7)$ & $132(43.7)$ & $139(46.0)$ & $37(12.3)$ \\
\hline Fair & $2(0.7)$ & $79(26.2)$ & $85(28.1)$ & $120(39.7)$ \\
\hline Poor & $0(0)$ & $85(28.1)$ & $4(1.3)$ & $112(37.1)$ \\
\hline Attractiveness of product & \multicolumn{4}{|l}{} \\
\hline Very attractive & $283(93.7)$ & $28(9.3)$ & $103(34.1)$ & $39(12.9)$ \\
\hline Attractive & $5(1.7)$ & $153(50.7)$ & $190(62.9)$ & $137(45.4)$ \\
\hline Not Attractive & $14(4.6)$ & $121(40.1)$ & $9(2.98)$ & $126(41.7)$ \\
\hline
\end{tabular}


3.5 Perception of processors on Yellow cassava utilization

As shown on Table 5, majority (95.0\%) of the processors strongly agreed that yellow root cassava is very rich in Vitamin A, 99.3\% agreed that consumption of yellow root cassava products can help prevent blindness in children and disease infection in reproductive women and $98.1 \%$ agreed that improvement in children growth and development can be achieved by feeding them with yellow root cassava products. The findings also revealed that most of the respondents did not agree with the statements that were not in favour of the $\mathrm{YC}$ and its products which was indicative of their favourable disposition to such statements. These perceptions of the respondents with respect to $\mathrm{YC}$ and its products could have been mostly shaped by the information they received from OYSADEP extension agents during the introduction of YC varieties to them. This implies that the processors have a good perception of $\mathrm{YC}$ and its products for consumption.

Table.5: Respondents' perception of Yellow cassava utilization

\begin{tabular}{|c|c|c|c|c|c|c|c|}
\hline $\mathbf{S} / \mathbf{N}$ & Perception Statements & $\mathbf{S A}$ & $\mathbf{A}$ & $\mathbf{U}$ & $\mathbf{D}$ & SD & Mean \\
\hline 1 & $\begin{array}{l}\text { Utilizing yellow root cassava is very rich } \\
\text { in Pro-Vitamin A }\end{array}$ & $\begin{array}{c}287 \\
(95.0)\end{array}$ & $15(5.0)$ & $0(0)$ & $0(0)$ & $0(0)$ & 4.95 \\
\hline 2 & $\begin{array}{l}\text { The yellow root cassava does not } \\
\text { produce good quality cassava products }\end{array}$ & $6(2.0)$ & $4(1.3)$ & $\begin{array}{c}8 \\
(2.6)\end{array}$ & $\begin{array}{c}92 \\
(30.5)\end{array}$ & $\begin{array}{c}192 \\
(63.6)\end{array}$ & 1.48 \\
\hline 3 & $\begin{array}{l}\text { Consumption of products from yellow } \\
\text { root cassava can help improve health } \\
\text { conditions of my family }\end{array}$ & $\begin{array}{c}141 \\
(46.7)\end{array}$ & $\begin{array}{c}157 \\
(52.0)\end{array}$ & $0(0)$ & $\begin{array}{c}2 \\
(0.7)\end{array}$ & $2(0.7)$ & 4.43 \\
\hline 4 & $\begin{array}{l}\text { Consumption of yellow root cassava } \\
\text { products can help prevent blindness in } \\
\text { children and disease infection in } \\
\text { reproductive women }\end{array}$ & $\begin{array}{c}165 \\
(54.6)\end{array}$ & $\begin{array}{c}135 \\
(44.7)\end{array}$ & $\begin{array}{c}2 \\
(0.7)\end{array}$ & $0(0)$ & $0(0)$ & 4.54 \\
\hline 5 & $\begin{array}{l}\text { Improvement in children growth and } \\
\text { development can be achieved through } \\
\text { feeding them with yellow root cassava } \\
\text { products }\end{array}$ & $\begin{array}{c}143 \\
(47.4)\end{array}$ & $\begin{array}{c}153 \\
(50.7)\end{array}$ & $\begin{array}{c}4 \\
(1.3)\end{array}$ & $0(0)$ & $2(0.7)$ & 4.44 \\
\hline 6 & $\begin{array}{l}\text { The appearance and colour of products } \\
\text { made from yellow root cassava are not } \\
\text { attractive to encourage its consumption }\end{array}$ & $8(2.6)$ & $4(1.3)$ & $\begin{array}{c}6 \\
(2.0)\end{array}$ & $\begin{array}{c}156 \\
(51.7)\end{array}$ & $\begin{array}{c}128 \\
(42.4)\end{array}$ & 1.70 \\
\hline 7 & $\begin{array}{l}\text { Many products cannot be made from } \\
\text { yellow root cassava compared to other } \\
\text { varieties }\end{array}$ & $\begin{array}{c}31 \\
(10.3)\end{array}$ & $24(7.9)$ & $\begin{array}{c}6 \\
(2.0)\end{array}$ & $\begin{array}{c}172 \\
(57.0)\end{array}$ & $69(22.8)$ & 2.26 \\
\hline 8 & $\begin{array}{l}\text { Consumers do not patronize products } \\
\text { made from yellow root cassava }\end{array}$ & $7(2.3)$ & $\begin{array}{c}58 \\
(19.2)\end{array}$ & $\begin{array}{c}29 \\
(9.6)\end{array}$ & $\begin{array}{c}167 \\
(55.3)\end{array}$ & $41(13.6)$ & 2.41 \\
\hline 9 & $\begin{array}{l}\text { Taste of yellow root cassava products is } \\
\text { not as palatable as products from other } \\
\text { cassava varieties }\end{array}$ & $22(7.3)$ & $8(2.6)$ & $\begin{array}{c}10 \\
(3.3)\end{array}$ & $\begin{array}{c}177 \\
(58.6)\end{array}$ & $85(28.1)$ & 2.02 \\
\hline 10 & $\begin{array}{l}\text { Consumption of yellow root cassava } \\
\text { products will help reduce the money that } \\
\text { I usually spend on my family members } \\
\text { as hospital }\end{array}$ & $\begin{array}{c}182 \\
(60.3)\end{array}$ & $\begin{array}{c}106 \\
(35.1)\end{array}$ & $\begin{array}{c}8 \\
(2.6)\end{array}$ & $\begin{array}{c}4 \\
(1.3)\end{array}$ & $2(0.7)$ & 4.52 \\
\hline 11 & $\begin{array}{l}\text { Quick discoloration of yellow root } \\
\text { cassava during processing makes it } \\
\text { unattractive to buyers and consumers }\end{array}$ & $14(4.6)$ & $20(6.6)$ & $\begin{array}{c}88 \\
(29.1)\end{array}$ & $\begin{array}{c}91 \\
(30.1)\end{array}$ & $89(29.5)$ & 2.27 \\
\hline
\end{tabular}

Figures in brackes are percentages

\subsection{Yellow Cassava attributes that determines its use by the processors}

Table 6 shows the importance of Yellow cassava attributes in its use by the processors. Majority (71.2\%) of the processors considered consumer acceptability of products from yellow cassava as important. However, other attributes such as ease of processing (67.5\%), taste of the products $(67.2 \%)$ and multiple usage of the tuber (65.9\%) were also considered important for its processing by the processors. This is similar to the findings of Agwu 
and Anyaeche (2007) who opined that high product quality, ease of processing and ability of the processed cassava to taste well to the consumer are reasons for continued use of some cassava cultivar.

Table.6: Attributes of Yellow Cassava that determines its use by the processors

\begin{tabular}{|l|l|l|l|}
\hline Attributes of Yellow Cassava & Very important & Important & Somewhat important \\
\hline Taste of the products & $40(13.2)$ & $203(67.2)$ & $59(19.5)$ \\
\hline Ease of Processing & $44(14.6)$ & $204(67.5)$ & $54(17.9)$ \\
\hline Consumer acceptability of the product & $33(10.9)$ & $215(71.2)$ & $54(17.9)$ \\
\hline Multiple usage of the tuber & $42(13.9)$ & $199(65.9)$ & $61(20.2)$ \\
\hline
\end{tabular}

3.7 Constraints faced by processors in the utilization of Yellow cassava

As shown in Table 7, majority non-availability of market for yellow root cassava products $(93.0 \%)$ of the respondents claimed that the constraints to the utilization of yellow root cassava were non-availability of market for yellow root cassava products, inadequate information on the potentials of yellow root cassava (90.4\%), non- acceptance of yellow root cassava products by the consumers (54.6\%) and inadequate knowledge about other products that can be made from YC (51.3\%). However, $42.1 \%$ and $23.2 \%$ of the respondents indicated that low or poor quality products as well as the appearance and colour of yellow root cassava products makes it unattractive to some consumers respectively.

Table.7: Constraints to the utilization of Yellow cassava

\begin{tabular}{|l|r|r|}
\hline Constraints & Yes & No \\
\hline Low or poor quality products & $127(42.1)$ & $175(57.9)$ \\
\hline Inadequate information on the potentials of yellow root cassava & $273(90.4)$ & $29(9.6)$ \\
\hline Non acceptance of yellow root cassava products by the consumers & $165(54.6)$ & $137(45.4)$ \\
\hline $\begin{array}{l}\text { Appearance and colour of yellow root cassava products that makes it } \\
\text { unattractive to the consumers }\end{array}$ & $70(23.2)$ & $232(76.8)$ \\
\hline Non availability of market for yellow root cassava products & $281(93.0)$ & $21(7.0)$ \\
\hline $\begin{array}{l}\text { Inadequate knowledge about other products that can be made from yellow } \\
\text { root cassava }\end{array}$ & $155(51.3)$ & $147(48.7)$ \\
\hline
\end{tabular}

3.8 Result of correlation analysis between attributes of yellow cassava and it's utilization by the processors.

The result of correlation analysis in Table 8 revealed there were positive and significant relationship between utilization of yellow cassava and the taste of its products $(\mathrm{r}=0.813)$, consumer's acceptability of the product $(\mathrm{r}=0.758)$ and multiple usage of the tuber $(\mathrm{r}=0.818)$. These results implied that the processors are likely to use Yellow cassava more as these attributes; taste of the products improves and the processing becomes easier. Also, acceptability of the products and its multiple use might increase the utilization of yellow cassava.

Table.8: Correlation analysis between attributes of yellow cassava and it's utilization by the processors

\begin{tabular}{|l|l|l|l|}
\hline Variables & r-value & $\boldsymbol{p}$-value & Decision \\
\hline Taste of the product & 0.813 & 0.000 & Significant \\
\hline Ease of Processing & 0.109 & 0.059 & Not Significant \\
\hline Consumer acceptability of the product & 0.758 & 0.000 & Significant \\
\hline Multiple usage of YC & 0.818 & 0.000 & Significant \\
\hline
\end{tabular}

$p \leq \mathbf{0 . 0 0 5}$

3.9 Chi-square result of relationship between selected socio-economic characteristics and utilization of Yellow cassava

The result of the chi-square test on table 9 shows sex $\left(x^{2}=30.141\right)$, marital status $\left(x^{2}=84.919\right)$, educational level has significant relationship with utilization of $\mathrm{YC}$ at $\mathrm{p} \leq 0.05$. The significant relationship between sex and utilization implies that gender affects the utilization of YC. This still emphasises the age long practice that women are more into the processing of cassava (Nweke et. al.,(2002) and Ogunleye, et.al. (2012). That of marital status implies that the married use YC as a major part of their meal. Also, the higher their education the more they utilize YC. This is because education influences ability to 
adopt innovation like various ways to process the variety. As the extension visits to the respondent increases their utilization of YC increases. This might be because respondents were enlighten more on the benefits of the consumption of the varieties and also because of the trainings received in the processing of the varieties to products which are good sources of additional income as well as increase the shelf life.

Table.9: Chi-square result showing the relationship between selected socio-economic characteristics and utilization of

Yellow cassava

\begin{tabular}{|l|l|l|l|l|}
\hline Socio economic Characteristics & $\boldsymbol{x}^{\mathbf{2}}$ value & df & p-value & Remark \\
\hline Sex & 30.141 & 10 & 0.001 & Significant \\
\hline Marital Status & 84.919 & 30 & 0.002 & Significant \\
\hline Educational level & 112.925 & 40 & 0.001 & Significant \\
\hline Extension visit & 48.656 & 10 & 0.001 & Significant \\
\hline Religion & 17.707 & 10 & 0.060 & Not Significant \\
\hline
\end{tabular}

\section{CONCLUSION AND RECOMMENDATIONS}

The study concludes that the processors who were mostly women were in there active age and majority had formal education. Awareness of YC (pro-Vitamin A cassava varieties) was substantial among the processors. Virtually all the respondents were aware of TMS 01/1368 variety of YC and majority of them were using this particular variety to produce Gari, and Fufu. Extension agents from the Oyo State Agricultural Development Programme (OYSADEP), Harvest plus and International Institute of Tropical Agriculture (IITA) formed the leading sources of information on YC varieties among the respondents. Most severe constraint experienced by the processors was non availability of market for yellow root cassava products. It is recommended that effort should be intensified on awareness campaigns about the benefit of the varieties to increase their use and invariably provide market for the products. Also, training should be organised for the processors from time to time to upgrade their knowledge to process more products that will have better taste that is acceptable to consumers.

\section{ACKNOWLEDGEMENT}

This work was supported by TETFUND Research Project Intervention Funds (year 2009/2010/2011/2012 merged) $6^{\text {th }}$ Batch RP Disbursement.

\section{REFERENCES}

[1] Aniedu, C. and Omodamiro, R. M. (2012). Use of Newly Bred $\beta$-Carotene Cassava in Production of Value-Added Products: Implication for Food Security in Nigeria. Global Journal of Science Frontier Research Agriculture and Veterinary Sciences. 12 (10); 11-15.

[2] Asonye C.C. (2001) Fortification of common Nigerian food-cassava meals. In Scrimshaw N.S. (ed) Dietary Approaches to Vitamin A Deficiency" Food and Nutrition Bulletin, 22 (4); 423-426.
[3] Agwu, A. E. and Anyaeche, C. L. (2007). Adoption of improved cassava varieties in six rural communities in Anambra State, Nigeria. African Journal of Biotechnology. 6 (2): 089-098.

[4] Agwu, A. E., Njom, P.C. and Umeh, B. U. (2017). Farmers Adoption Scenarios for the Control of Cassava Mosaic Disease under the Cassava Enterprise Development Project in Enugu State, Nigeria. Journal of Agricultural Extension, 21 (1); 208

[5] Berrisso, Z.A. (2008). Analysis of GIS adoption process based on organizational changes and decisions: Case of municipal utility Organization in Addis-Ababa, Ethiopia. Unpublished thesis submitted to international institute of for GeoInformation science and Earth science, Netherland.

[6] Echebiri, R.N., Edaba, M.E.I., (2008). Production and utilization of cassava in Nigeria: Prospects for Food Security and infant nutrition. PAT 4, $38-52$.

[7] Erhabor, P.O; and Emokaro C.O (2007). Economic importance of cassava, in: Erhabor, P.O; Azaiki, S.S and Ingawa, S.A (eds.), Cassava the white gold, pp116, Benin City, Nigeria, Initiative publication.

[8] 8. Manyong, V. M. and Houndekon, A.V. (1997). Land tenurial systems and the adoption of mucuna planted fallows in the derived savanna of West Africa. Paper presented at the workshop on property rights, collective action and technology adoption. ICARDA. November, 22-25, Aleppo, Syria.

[9] Maziya-Dixon, B., Dixon, A.G.O., Adebowale, A.R.A.,(2007). Targeting different end uses of cassava: genotype variations for cyanogenic potentials and pasting properties. Inter. J. Food Sci. Technol. 42, 969 - 976.

[10] Oparinde, A., Banerji, A. Birol E. and Ilona, P. (2014). Information and Consumer Willingness to Pay for Biofortified Yellow Cassava: Evidence from 
Experimental Auctions in Nigeria. HarvestPlus Working Paper No.13

[11] Nuwamanya, E., Baguma, Y., Emmambux, N., Rubaihayo, P., (2010). Crystalline and pasting properties of cassava starch are influenced by its molecular properties. Afr. J. Food Sci. 4,008 - 4,015

[12] Nweke, F.I; Spencer, Duntan S.C and Lynam, John K. (2002). The cassava Transformation: Africa's Best-Kept Secret. Michigan state university press, East Lansing. Michigan, U.S.A, pp 129-143.

[13] Ogunleye, K. Y., Olaniyi, O. A. and D. I. Adedeji (2012): Assessment of Training Needs of Cassava Processors for Increased Productivity in Ogbomoso Agricultural Zone of Oyo State. International Journal of Agricultural Economics \& Rural Development 5 (1):10-17

[14] Ojo, M.A. and Jibowo, A. A. (2008) Socioeconomic Characteristics Influencing Role

System in Osun State, Nigeria: Journal of Agriculture and Rural Development, 2: 27 40

[15] Oparinde, A., Banerji, Birol, E. and Ilona, P. (2014). Biofortified Yellow Cassava: Evidence from Experimental Auctions in Nigeria. HarvestPlus Working Paper No. 13.

[16] Oseni Y., Nwachukwu W., and Usman Z. A. (2015). Measurements of Technical Efficiency and its Determinants in Sampea-11 Variety of Cowpea Production in Niger State, Nigeria. International Research Journal of Agricultural Science and Soil Science, 5(4): 112 - 119

[17] Osiru D.S.O, Hahn S.K., Osunubi, B. (1992). Varietal response to drought stress in cassava. In: Okoroda M.O., Arene O.B., eds. Tropical root crops: promotion of root crop-based industries. Ibadan, Nigeria: International Society for Tropical Root Crops, Africa Branch. pp 97-103.

[18] Tumuhimbise, G.A., Namutebi A., Turyashemererwa, F., Muyonga, J. (2013). Provitamin A Crops: Acceptability, Bioavailability, Efficacy and Effectiveness. Food and Nutrition Sciences 4: 430-435

[19] Umunakwe, P.C., Nwakwasi, R. N. Ani, A. O., Ejiogu-Okereke E. N. and Nnadi, F. N. (2015). Constraints to the Adoption of Improved Cassava Varieties among Rural Farmers in Imo State, Nigeria. Asian Journal of Agricultural Extension, Economics and Sociology, 6(1): 56-63.

[20] Wejnert, B. (2002). Integrating models of diffusion of innovations: A conceptual frame work. Annual Review of Sociology, 28: 297 - 306.

[21] WHO/FAO, (2003)."Diet, Nutrition and the Prevention of Chronic Diseases," Report of the Joint
WHO/FAO Expert Consultation, WHO Technical Report Series, WHO, Geneva.

[22] WHO (2017). Micro Nutrients Deficiency: Vitamin A Deficiency. www.who.int/nutrition/topics/vad/en/ Retrieved on 5th August, 2017 